\title{
Orobio Contra Prado: A Trans-European Controversy
}

When the college "Mother of God of the Theologians" at the University of Alcala de Henares elected Baltasar Orobio de Castro on April 20, 1636 as one of its members, the young medical student owed his admission perhaps to the intervention of another Andalusian converso, Juan de Prado, with whom he had been acquainted for three years in a friendship apparently based on the two men's common crypto-Judaism. ${ }^{1}$ From then until Prado's death in 1669, they would repeatedly come together in different places in Europe. In their own way, they symbolised the two sides of the Iberian New Christians' exile and their conversion to Judaism. Orobio embodied a successful process of Judaisation in which he would eventually become the spearhead of orthodoxy, while Prado illustrates, if not the failure, at least the torments and spiritual comings-and-goings that were interwoven in this process. Their singularity, however, is that they represented a conspicuous category among the New Christian emigrants: intellectuals who, as Orobio pointed out in his Invective Epistle, had attended Iberian universities and later joined normative Jewish communities. ${ }^{2}$ Both Prado and Orobio did so at more than 40 years of age, after protracted peregrinations across Europe: while the former had left for Rome, the latter went to France. In 1663-1664, when Orobio had proceeded to Amsterdam and Prado to Antwerp, they engaged in an epistolary dispute that marks the clash between their respective tendencies towards Jewish belief and free-thinking doubt. This controversy shows that both conversos adopted normative Judaism reluctantly, and it also shows that, vice versa, many of their coreligionists born into Judaism had difficulties in understanding them. The peculiar interest of this controversy lies in the fact that Orobio was himself a former crypto-Jew and that he noticed Prado's intellectual ferment at a time when both were still living in Spain. It is crucial to note, though historiography has tended to neglect this aspect, that their confrontation started well before both of them converted to Judaism. Prado's doubts reflect a spiritual dynamic of Spanish origin, a form of scepticism and deism that appears among converso intellectuals, even among secret Judaisers, but also in Iberian societies as a whole. The difficulty is that most if not all positions of Prado's thought can only be grasped negatively, be it through the in-

Natalia Muchnik, École des Hautes Études en Sciences Sociales, Paris

1 This might be one of the "favours" which Orobio mentions in his Carta apologética, edited in I.S. Révah, Spinoza et le Dr Juan de Prado (Paris: Mouton \& Cie., 1959), 130: "yo no he recivido algunos agravios del Doctor Prado, sino repetidas y continuadas experiencias de su buena voluntad y deseo de mis medras, sin olvidar los favores y assistencias en los primeros años de mi juventud."

2 Orobio, Epístola invectiva, in Révah, Spinoza, 89.

Ә OpenAccess. (c) 2018 Natalia Muchnik, published by De Gruyter. (cc) BY-NC-ND This work is licensed under the Creative Commons Attribution-NonCommercial-NoDerivatives 4.0 License. 
quisitorial archives, biased by definition, or through the writings of Orobio and other Jewish opponents.

\section{Andalusian Medical Circles and the Birth of a Friendship}

The interest of the confrontation between Orobio and Prado lies in particular, as has been said, in the long history of their relationship and in the similarities between their backgrounds and itineraries. Prado, born around 1612, was only five years older than Orobio; both originated in the region of Bragança and were brought to Andalusia during their childhood. Their families who were part of the trans-Iberian migration wave of conversos fleeing the very active Portuguese Inquisition, wanted to take advantage of the economic opportunities they could find in Spain at a time when both kingdoms were united under the same monarch. While Orobio's family settled in Málaga, the Prados chose Lopera, a town in the region of Jaén. Juan de Prado started his medical studies at the University of Alcalá in 1627, whereas Baltasar enrolled five years later at the University of Osuna. Orobio moved to Alcalá in 1635 and entered one year later the "College of the Mother of God," where Prado had been a member since $1633 .^{3}$ Prado did not finish his schooling there, but left Alcalá for the University of Toledo. This is what one can conclude from the fact that he presented a doctoral diploma from that university, obtained in 1638, when he enrolled in the College of Physicians of Amsterdam in $1655 . .^{4}$ This document was probably a forgery, just like the doctoral certificates that Orobio presented in Seville in 1641 and in Toulouse in $1660 .^{5}$

Did the two men become acquainted with each other during the year of 16351636 when they studied together in Alcalá? This is more than likely. Did they secretly share Jewish beliefs and ceremonies with each other? No explicit source indicates this. We do not know anything certain about young Prado's cultural practices. If we accept Orobio's testimony in his Invective Epistle, he observed the Jewish law since his childhood; and Prado himself, in a letter he sent in 1667 to the Holy Office, searched to excuse his Judaism with the misguided upbringing that he received. ${ }^{6}$ However, inquisitorial evidence suggests that Prado converted both his relatives

3 I. S. Révah, Des Marranes à Spinoza, edited by Henry Méchoulan, Pierre-François Moreau and Carsten Lorenz Wilke (Paris: Vrin, 1995), 260 -263; Natalia Muchnik, Une vie marrane: Les pérégrinations de Juan de Prado dans l'Europe du XVIIe siècle (Paris: Honoré Champion, 2005), 85-93.

4 Révah, Des Marranes à Spinoza, 262.

5 Yosef Kaplan, From Christianity to Judaism: The Story of Isaac Orobio de Castro (Oxford, Littman Library; Oxford University Press, 1989), 101-102.

6 Révah, Des Marranes à Spinoza, 257-258; Muchnik, Une vie marrane, 332-333. 
and his friend Orobio. "He said that nobody had encouraged or taught him to observe the Law of Moses, but he had learned it from his books and studies."7

The friendship of the two medical doctors continued after their studies. One rediscovers them side-by-side in certain scholarly meetings, tertulias, which brought together, in Andalusia, several doctors, all of them being apparently of converso stock. This is at least what Orobio would declare in front of the inquisitors of Seville, who reported in 1656 to the High Council of the Holy Office:

Attached to the present letter, we submit to Your Highness the trial record and the testimony that Doctor Don Baltasar de Orobio, a physician, inmate in the secret prisons of this tribunal, has given against the Doctors Pereda, Simón de Silva Calvo, the latter resident of Murcia, Reynoso, Núñez, and Juan de Prado, the latter resident of Antequera, and the Licenciate Serrano, resident of Bailén, who are all physicians and have been voted to be arrested with confiscation of their property, as Your Highness may command to see. Because he has, when speaking of the aforementioned persons, only declared the places of residence of the Doctors Silva in Murcia and Juan de Prado in Antequera, as well as of the Licenciate Serrano in Bailén, Your Highness may order to execute the steps that the respective inquisitorial tribunals will agree upon. ${ }^{8}$

It is not surprising that the inquisitors took a keen interest in these doctors whom they suspected of holding leadership roles in the converso communities, taking advantage of their mobility and prestige in order to disseminate Judaising practices. The fellow doctors denounced by Orobio can be identified from other sources: Diego Duarte Serrano, of Bailén in the province of Jaén, is Prado's brother-in-law, since he was married to the sister of Isabel Gómez, wife and cousin of Prado since 1638. It seems, moreover, that Prado and Duarte were fellow students at Alcalá, where they are found side-by-side in the records of 1631 and $1633 .{ }^{9}$ Dr. Núñez may have been Duarte Núñez de Acosta, a student of Salamanca and later a physician of the aristocracy, probably from a crypto-Jewish family, who participated in 1653 in a medical controversy at the University of Seville that brought together various doctors of the region, among them Orobio. But Dr. Núñez can alternatively be identified with Jorge Nuñez, a student in Alcalá belonging to Prado's circle, who may perhaps be found around 1649 among the Jews of Livorno. ${ }^{10}$ As for Jerónimo Gómez Pereda, he was a royal physician linked to the great Portuguese families of Madrid and

7 Archivo Diocesano de Cuenca [ADC], Inquisición, leg. 492 (6569), fol. 77r: "deçia que a el no le avia impuesto nadie en la observançia de la ley de Moyses, ni se la avia enseñado sino que el la avia aprendido por sus libros y letras.” Cf. Révah, Des Marranes à Spinoza, 278; Muchnik, Une vie marrane, 121.

8 Archivo Histórico Nacional [henceforth AHN], Inquisición, leg. 2987', published by I. S. Révah, "Aux origines de la rupture spinozienne: Nouveaux documents sur l'incroyance dans la communauté judéo-portugaise à Amsterdam à l'époque de l'excommunication de Spinoza," Revue des études juives 123 (1964): 359-431, here $430-431$.

9 They sign jointly the certificate of the medicine and surgery classes, see AHN, Universidades, lib. 493F, fol. 5r-v (1632-1633); see Muchnik, Une vie marrane, 85-86.

10 Kaplan, From Christianity to Judaism, 88, note 39; Muchnik, Une vie marrane, 91. 
the diaspora. Educated at the University of Sigüenza, he became Prado's uncle by alliance, and he had also taken part in the same student circle of Alcala, since Orobio declared that Pereda was the one who converted him to Judaism:

\begin{abstract}
Doctor Juan de Prado, a Portuguese physician resident of Antequera, where he was living when the declarant [Orobio] was arrested, is an observer of the said Law of Moses, because during the time he has declared about, that is, sixteen years ago, when the declarant was studying at the University of Alcalá, where Doctor Prado's uncle, the Doctor Pereda, taught and instructed him in the observance of the said Law of Moses, the said Prado declared himself with the declarant as an observer of the Law of Moses, because he had known and understood that his said uncle Pereda had become and remained the declarant's teacher. They talked about the ceremonies that were obligatory to perform for the said observance and salvation of one's soul, though he does not remember having performed any of them together with him. ${ }^{11}$
\end{abstract}

One can discover in Orobio's declaration a hint to a crypto-Judaic circle that seems to have existed during the 1630s at Alcalá and, more specifically, among the medical students. Some of its members would later reconstitute their circle in Andalusia and, once more, in emigration outside Spain, particularly in the Jewish diaspora community of Amsterdam. It is very likely that the "Doctor Reynoso" denounced by Orobio is the same person as Miguel Reynoso, who settled in Amsterdam around 1646, whom one finds alongside Prado and Spinoza in 1659, and who signs in 1673, jointly with Orobio, a notarial act concerning a woman patient. ${ }^{12}$ This Reynoso seems to be identical with Dr. Abraham Israel Reynoso, who entered the brotherhood Honen Dalim in 1645-1646, was elected to the mahamad in 1654 and registered in the Collegium Medicum of Amsterdam. ${ }^{13}$

How should we imagine these Andalusian medical tertulias? They probably resembled the academic disputations that Orobio used to take part in at the time, such as the one held in Seville, in 1653, about bloodletting. Discussions must have easily slipped from medicine to philosophy and even theology. As proof, one of the participants in the bloodletting controversy, Dr. Sebastián Soto, whom the Inquisition of Toledo had accused in 1634 of erroneous propositions (he had alleged that

11 AHN, Inquisición, leg. 2987': "El Doctor Joan de Prado medico portugues vecino de Antequera a donde residia quando este [Orobio] fue preso es observante de dicha ley de Moisen porque el tiempo que ha dicho de diez y seis años que este estava en la Universidad de Alcala donde le enseño e ynstruio como tiene dicho en la observancia de la dicha ley de Moisen el dicho Doctor Pereda tio del dicho Prado este dicho Prado se declaro con este por observante de dicha ley de Moisen porque supo y entendio que el dicho su tio Pereda en la dicha observancia de la ley de Moisen avia sido y era Maestro deste [Orobio] no se acuerda hicieran ceremonias juntos pero comunicabanse en las que havian de hacer que heran las convenientes para la dicha observancia y la salvacion de su alma." French translation in Muchnik, Une vie marrane, 95.

12 Kaplan, From Christianity to Judaism, 204.

13 Stadsarchief Amsterdam [henceforth SAA], PA 334, no. 1186, fol. 58v; no. 19, in the lists at the beginning of the volume; SAA, Collegium Medicum, Series nominum doctorum medicinae, no. 16: "Michael Reynosa jam dictus Abraham Reynoso Hebraeus"; see Muchnik, Une vie marrane, 173-174. 
God did not intervene in secondary causes), evoked the tertulias held every Monday among doctors in order to discuss, in particular, matters of philosophy and theolo$\mathrm{gy}^{14}$

Not incidentally, Orobio first remarked during this period that Prado was harbouring doubts about the religious faith, and he seems already to be fighting his friend's objections, as he would again with greater firmness twenty years later, in Amsterdam.

\section{First Struggles and First Doubts}

After his university studies, Prado was busy spreading crypto-Judaism, as Orobio would later note in his Invective Epistle, "trying to win over for its observance others of the same nation who were lacking instruction and, by consequence, belief. To these, he repeatedly quoted the verse: 'He has not done this to all nations, and He did not reveal his judgments to them' [Ps 147:20]." At the time, Prado "found natural reasons of utmost acumen in order to convince certain stubborn hearers of the truth."15

Around 1643, when Orobio taught at the University of Seville, he paid a visit to Prado. As he declared to the Holy Office, Baltasar noted with astonishment that his friend "appeared changed in some of his answers" to such an extent that he could only display his incomprehension at his propositions. When he pushed Prado to explain himself,

he told him, though with some hesitation in his reasoning, that all humans could obtain salvation, each and everyone in the law that they observed, whether they were Jews, Moors, or Christians, because their laws tended toward a political finality derived from the natural law, and this was the causa causarum that Aristotle had recognised. ${ }^{16}$

14 Sagrario Muñoz Calvo, Inquisición y ciencia en la España moderna (Madrid: Editora Nacional, 1977), 188-191.

15 Orobio, Epístola, in Révah, Spinoza, 109: "la abrazó y observó [la Divina Ley] desde la infancia hasta los años de la senectud entre peligros y zozobras de sus enemigos, procurando atraher a la mesma observancia a otros de la propria nacion que, por falta de doctrina, estavan incredulos, repitiendo diversas veces el verso: No hizo assi a toda nacion, y sus juicios no manifestó a ellos ... Entonces se ofrecian razones naturales con summa agudeza para persuadir la verdad a algun obstinado." 16 AHN, Inquisición, leg. $2374^{1}$, fol. 2r-v: "El Dr Joan de Prado medico dijo a este que tenia por cierto que se salvaba cada uno en la ley que profesava el cristiano en la suia, y en la de Moisen, y Mahoma los que las profesavan y seguian como en todas las demas porque como miraban todas a un fin que hera reconoçer a Dios eso bastava para salvarse.” This testimony is reported in a file composed around 1669 by the inquisitorial tribunal of the Canary Islands; see Révah, Des Marranes à Spinoza, 279; Muchnik, Une vie marrane, 342-343. 
Are we facing here the first doubts and the beginnings of the deism that would come to the fore in Amsterdam fifteen years later? During the ratification of his confession, Baltasar pointed out that Dr. Diego Duarte Serrano, Prado's brother-in-law who, as we have seen, participated in the same tertulias, attended their conversation and approved of Prado's reasoning. However, Orobio now presents Prado's words quite differently:

Dr. Juan de Prado, the physician, said to the declarant that he was sure that everyone obtained salvation in the law they confessed: the Christian in his one, and those who confess and follow the laws of Moses and Mahomet obtain it through theirs, and likewise all others, because all [laws] were directed towards the finality of knowing God, which is sufficient for salvation. ${ }^{17}$

These two, seemingly irreconcilable versions have posed a problem to historiography. ${ }^{18}$ They may lead to several hypotheses about Prado's thought: are the laws of religion merely political and pragmatic, or do all religions aim at the knowledge of God? Does religious faith only assure political obedience or can it help in finding speculative certainty? However, one may answer this question, it is manifest that already in the early 1640s, Prado nourished heterodox thoughts and betrayed the first signs of deism, an incredulity that Orobio later attributed to

the Godless persuasion of another man of the Hebrew nation, first Christian, then Jewish, then neither Jewish nor Christian, a very short-minded fellow, a meagre philosopher and even less of a physician, foolish in his discourse, intrepid in his speech, a lover of novelties, a cultivator of paradoxes, and worst of all, a man of abominable customs. ${ }^{19}$

Orobio does not name the crypto-Jewish yet free-thinking doctor who had perverted Prado. I.S. Révah identified this third man with a certain Juan Piñero, whose name appears in the margin of several copies of the Invective Epistle next to the quoted passage. This Sevillian, who died around 1662, is denounced in the inquisitorial trial of another Judaising doctor, Rodrigo Enríquez de Fonseca, who seems to have been his fellow student in Alcala before a professor at the University of Valencia con-

17 AHN, Inquisición, leg. $2374^{1}$, fol. 3r: "El Dr Joan de Prado medico dijo a este que tenia por cierto que se salvaba cada uno en la ley que profesava el cristiano en la suia, y en la de Moisen, y Mahoma los que las profesavan y seguian como en todas las demas porque como miraban todas a un fin que hera reconoçer a Dios eso bastava para salvarse.” Révah, Des Marranes à Spinoza, 279; Muchnik, Une vie marrane, 343.

18 Yirmiyahu Yovel, Spinoza and Other Heretics, Vol.1. The Marrano of Reason (Princeton: Princeton University Press, 1989), 62.

19 Orobio, Epístola, in Révah, Spinoza, 109: "Y si se inquiere el fundamento desta mudanza y nueva incredulidad, no es otro que rendir el antiguo y bien fundado dictamen a la persuasion de otro, Hebreo de nacion, primero Christiano, despues Judio, y despues ni Judio ni Christiano: hombre de cortissimo juizio, poco Philosopho y menos Medico, loco en su discur[r]ir, intrepido en su hablar, amigo de novedades, solicitador de paradoxas y, lo peor, abominable en sus costumbres." The manuscript Amsterdam, Ets Haim, ms. 48 C 04, fol. 17r, reads "la ympia persuacion de otro Hebreo de nascion." 
verted him to a religion based on the Law of Nature. ${ }^{20}$ Orobio mentions Piñero in another context, when he remembers that he had once borrowed from him the Scrutinium Scripturarum of Pablo de Santa Maria. ${ }^{21}$

One can safely conclude that deist ideas did indeed circulate among New Christian students at Spanish universities in the seventeenth century. The schools of Alcalá and Valencia, which were particularly notorious hotbeds of novatores, also became way stations in the biography of various Judaising doctors, such as Diego Mateo Zapata, one of the foremost novatores himself. Historiography has repeatedly pointed out the link that connected sixteenth- and seventeenth-century crypto-Judaism to medicine and a specific form of incredulity that has been categorised as materialism, naturalism or even atheism, a trilogy of which Prado may seem to be the very embodiment. Historians of the Inquisition have observed that trials against conversos frequently append charges of incredulity to the ordinary accusations of crypto-Judaism. ${ }^{22}$ The existence of rationalist or "averroist" tendencies among the Jews and, later, the conversos of Spain is manifest since the Middle Ages. According to Yitzhak Baer, Spanish rabbis complained of the numerous Jews who affirmed that the soul was mortal, who held the natural laws superior to the Torah, and who pursued secular rather than religious knowledge. ${ }^{23}$ In the sixteenth century, authors such as João de Barros in his Ropicapnefma (1532) attack conversos who reject the dogmas of the immortality of the soul and of the rewards and punishments in the afterlife. ${ }^{24}$ Many trials against crypto-Judaisers thus involve doubts about immortality and afterlife. To be sure, such accusations are also prolific in the inquisitorial trials opened against Old Christians for "propositions," "scandalous words," or stereotyped expressions such as "there is nothing in life but to be born and die" or "we are born and die like beasts." However, similar manifestations of unbelief were associated with Judaisers, as were blasphemies, scepticism, and other forms of nonconformist thought. ${ }^{25}$

20 AHN, Inquisición, lib. 1134, fols. 204r. and 149r-v.

21 Orobio, Carta apologética, in Révah, Spinoza, 132; see Révah, Des Marranes à Spinoza, 269-272. 22 Julio Caro Baroja, Los judíos en la España moderna y contemporanea (Madrid: Istmo, 2000) [1961], vol. 1, 493; Caro Baroja, De la superstición al ateismo: Meditaciones antropológicas (Madrid: Taurus, 1974), 255.

23 Yitzhak Baer, A History of the Jews in Christian Spain, trans. Louis Schoffman (Philadelphia: Jewish Publication Society, 1966 [1945]), II 253 - 259, chapter “Averroism among the Jews.” On Baer’s thesis, see Yosef Kaplan, "Foi et scepticisme dans la diaspora des nouveaux-chrétiens des débuts de l'Europe moderne," Arquivos do Centro Cultural Calouste Gulbenkian 48 (2004): 21-40, here 24-25. 24 I. S. Révah, "Le colloque 'Ropicapnefma' de João de Barros. Genèse, structure et technique," Bulletin Hispanique 64bis (1962), 572-592, and Révah, “Antiquité et christianisme, anciens et modernes, dans l'œuvre de João de Barros,” Revue philosophique de la France et de l'étranger, 157 (1967), 165185; Kaplan, "Foi et scepticism," 33.

25 John Edwards, "Religious Faith and Doubt in Late Medieval Spain: Soria circa 1450-1500," Past and Present, 120 (1988), 3-25; Juan Antonio Alejandre and María Jesus Torquemada, Palabra de hereje: La Inquisición de Sevilla ante el delito de proposiciones (Seville: Universidad de Sevilla, 1998); J. 
In this perspective, incredulity was disseminated in alliance with a sort of crypto-Judaism that one may certainly imagine as a secular rather than religious attitude, an attitude for which Prado was characterised as a premature "secular Jew."26 Quite a similar mindset appears, coloured with blasphemy, in the words of Fernando de Medina, born in 1656 in Peyrehorade in southwestern France and arrested in New Spain in 1691 on accusations of Judaising. He maintained, however: "There is no God, no deity, no Trinity: the gods are men of flesh and blood like all others." "Soul is spirit, and when the body dies, ... the spirit dies too." Eight years later, Fernando concluded, like Prado, that "men can obtain their salvation through any law and any sect."27

However, these currents also must be located inside Spanish intellectual history. Various sources affirm the existence of so-called "atheist" thinkers who, inspired in part by models from Greek and Roman Antiquity, subscribed to the thesis of the mortality of the soul and did not believe in post-mortem rewards. Since the sixteenth century, the cases of such alleged heretics multiplied. Though these people evoked the same slogan of "to be born and to die is all," they had no connection whatsoever with crypto-Judaism. Works such as the Ten Laments on the Misery of the Atheists of our Time by friar Jerónimo Gracián (1611) attempt to reveal the existence of these unbelievers, which the defenders of the faith falsely described as atheists. ${ }^{28}$ In order to confute these deviant minds, Quevedo contributed texts of political or ascetic veins such as the Politics of God and Government of Christ and the Providence of God, which Confutes its Deniers and Favours its Confessors, books written around 1617 and 1641, respectively. In the Politics of God, Quevedo creates an association between reason of state and atheism, two idols inseparable from their two attributes, dissimulation and incredulity. ${ }^{29}$ According to him, the "Godless" ( $\sin$ Dios) are "those who do not believe in the immortality of the soul, those who say that there is neither God nor Providence, and those few who confess that there is a God but deny His providence." ${ }^{30}$

Edwards and C. John Sommerville, "Religious Faith, Doubt and Atheism," Past and Present, 128 (1990): 152-161, here 156.

26 Yirmiyahu Yovel, The Other Within: The Marranos, Split Identity and Emerging Modernity (Princeton: Princeton University Press, 2009), 333.

27 Nathan Wachtel, La foi du souvenir: Labyrinthes marranes (Paris: Seuil, 2001), 240-244, 246. 28 Geronimo Gracian de la Madre de Dios, Diez lamentaciones del miserable estado de los Atheístas de nuestros tiempos (Brussels: Roger Velpio and Huberto Antonio, 1611); cf. Caro Baroja, De la superstición al ateísmo, 258-260.

29 Quevedo, Política de Dios y gobierno de Cristo (Buenos Aires: Espasa-Calpe Argentina, 1947), 123. 30 Quevedo, Providencia de Dios padecida de los que la niegan y gozada de los que la confiessan: Doctrina estudiada en los gusanos y persecuciones de Job (Zaragoza: Pasqual Bueno, 1700), 3: "Estos hombres se llaman en Griego, sin Dios, con esta palabra Atheistas, que se han vsurpado las lenguas vulgares. Los que no creen la Immortalidad de la Alma, dizen, que ni ay Dios, ni Providencia; y son muy pocos los que la niegan, que confiessen hay Dios, mas estos negaron su Providencia." 
They deny the afterlife and perceive all religions as lies: Quevedo here possibly hints to certain expressions of the "Three Impostors" topos. ${ }^{31}$

On the Jewish side, Fernando (Isaac) Cardoso claims to have composed a "book on the Six Days [of creation] against the atheists for the defense of the soul." $32 \mathrm{He}$ reiterates his attacks in his Philosophia Libera, published in Italy but partly written in Spain: "The assertors of the mortality of the soul, whom I have myself known, were wicked men, devoted to vices, and bound to no law." 33 Similarly, many literary writings of the Spanish baroque, such as the allegorical Corpus Christi plays (autos sacramentales) by Lope de Vega and Calderón de la Barca, present characters designated as sceptics or atheists, without necessarily attributing the political motivations of the reason of state to them. Finally, in treatises on theology, one can observe the regular appearance of introductory chapters aimed at demonstrating the existence of God, a genre that was still rare in the sixteenth century. ${ }^{34}$ The Jesuits, in particular, devote much space to this question. ${ }^{35}$

In sum, the doubts that Orobio perceived in Prado and that he denounced to the Holy Office in 1654-1656 fit into a well-known dynamic that took place both inside and outside crypto-Judaism. When making his declarations, he probably knew that Prado was by then already out of Spain. The latter had become in 1652 the personal physician of Domingo Pimentel, Archbishop of Seville, who had just obtained the dignity of Cardinal, and accompanied him on a journey to Rome. When Pimentel died in 1653, Prado and his family had to make a new start, this time joining the Sephardic community of Hamburg. Juan de Prado, who adopted the first name of Daniel after his circumcision, settled in Amsterdam in 1655. Orobio would join him there in 1662.

31 Quevedo, Providencia de Dios, 28.

32 Cardoso, Discurso sobre el Monte Vesuvio (Madrid: Francisco Martinez, 1632), fol. 5r-v: "como diximos cõtra el Atheista en nuestra obra de los Seis dias en defensa del alma."

33 Cardoso, Philosophia Libera, book VI "De immortalitate animae." I follow the translation in Yosef Hayim Yerushalmi, From Spanish Court to Italian Ghetto: Isaac Cardoso, a Study in Seventeenth-Century Marranism and Jewish Apologetics (New York: Columbia University Press, 1971), 254.

34 Ramón Ceñal, "El argumento ontológico de la existencia de Dios en la escolástica de los siglos XVII y XVIII,” in Homenaje a Xavier Zubiri (Madrid: Moneda y Crédito, 1970): 247-325.

35 See, for instance, Francisco Suarez, Metaphysicarum disputationum (Salamanca, Juan and Andres Renaut, 1597) and Pedro Hurtado de Mendoza, Disputationes de universa philosophia (Lyon: Antoine Pillehotte, 1614-1617). 


\section{The Devices of Prado's Thought}

"It is only to you that it so happened, to be a fake Christian and a true Jew where you could not be a Jew, and to be a fake Jew where [finally] you could be truly Jewish." 36 In these terms, Orobio lambasts Prado in his Apologetic Letter. He had started his text with the statement that he desired "to accelerate his repentance, to where the knowledge of the truth that he had previously observed, and that his parents had kept, is about to bring him, according to the news I received." ${ }^{37}$ We know indeed that in July 1656, less than one year after Prado's arrival in Amsterdam, he was excluded together with Spinoza from the Portuguese Jewish congregation by its authorities.

Prado had met the young Baruch Spinoza before the end of 1655. Certain scholars, such as Carl Gebhardt and I. S. Révah, have maintained that Spinoza, who had until then been an active member of the congregation, was among the students that Prado "seduced" with his ideas. This is manifestly what Orobio believed and expressed in his writings; and so did Miguel de Barrios in his famous verses: "Now thorns (espinas) are there where roses stood yesterday, and the asp that can be seen in its leaves, aims at the one who passes poisonous darts." 38 These lines were published in Barrios's Coro de las Musas in 1672, two years after Spinoza's Theological-Philosophical Treatise was published; they are still absent from the first version of the poem, which had appeared in the volume Flor de Apolo in 1665. However, in the light of what we know on Spinoza's early life, it seems likely that Prado was not really a mentor for him, but that their encounter was merely a catalyser for the doubts that he had previously harboured. The same may be said for Prado himself. Some scholars, most decidedly Gabriel Albiac and Yirmiyahu Yovel, claim an influence of the marranic experience on Spinoza while downplaying Prado's individual role in it. ${ }^{39}$ Still more numerous are those scholars who look for heterodox influences from outside the Sephardic community. ${ }^{40}$ Richard Popkin, who ignored the prece-

36 Orobio, Carta apologética, in Révah, Spinoza, 133: "que solo a Vmd. aconteció ser Christiano fingido y Judio verdadero en donde no podía ser Judío, y ser Judío fingido en donde podía serlo verdadero.” Translation quoted from Yovel, Spinoza and Other Heretics, vol. 1, 63.

37 Orobio, Epístola invectiva, in Révah, Spinoza, 93: "tengo esperanza que le traerà al conocimiento de la Verdad que observe"; corrected according to the ms. Ets Haim 48 C 04, fol. 4v: "tengo noticias le trae el conocimento de la verdad que antes observe."

38 Miguel de Barrios, "Epistola censorial," in Révah, Spinoza, 80: "Agora espinas son las que ayer rosas, / y el aspid que en sus hojas se apercibe, / hinca al que passa puntas venenosas." On the common puns linking the thorns (espinas) to the meadows (prados), see Práxedes Caballero, "La crítica de Orobio de Castro a Spinosa," in Spinoza y España, edited by Atilano Domínquez (Murcia: Universidad de Castilla-La Mancha, 1994): 229-237, here 232.

39 Gabriel Albiac, La sinagoga vacía: Un estudio de las fuentes marranas del espinosismo (Madrid: Hiperión, 1987), and Yovel, Spinoza and Other Heretics, Vol. 1, 80: "Prado and Spinoza arrived at their heretical ideas independently."

40 Koenrad O. Meinsma, Spinoza et son cercle (Paris: Vrin, 1983) (revised version of the original edition of 1896), Filippo Mignini, "Données et problèmes de la chronologie spinozienne entre 1656 et 
dents of deism in Prado's Spanish past, supposed that for both men, a turning-point must have been the Amsterdam visit of Isaac La Peyrère, who published his Praeadamitae there in $1655 .{ }^{41}$ In this book, he argues that there is no evidence of the world being created; moreover, since the historical records of the Chinese date back more than ten thousand years, it is likely that their origin is earlier than that of the Jewish people-an argument that we find again in Prado. References to "the pre-Adamite sect of Amsterdam" exist in the polemics that were published against La Peyrère after 1656. In the controversy that pitted Orobio against Philip van Limborch, the former speculated about a connection between "pre-Adamites," "atheists," and "theological politicians." 42 Certain stances held by Prado, especially his doubt in the accuracy of biblical information, which must have to some extent been shared by the young Spinoza as well, ${ }^{43}$ coincide (according to Popkin) with the religious scepticism ${ }^{44}$ promoted by La Peyrère. Their stance involves an understanding of the sacred text as a document that needs to be understood from itself, following a specific type of knowledge and establishing an "archaeology that needs to construct a science of meaning." ${ }^{45}$ Other historians of philosophy have emphasised the impact of Franciscus van den Enden, Spinoza's Latin teacher, who is thought to have inspired the theoretical foundations of the Spinozist system. ${ }^{46}$ Finally, certain scholars insist on the precocious philosophical originality of the young Spinoza (see the biographies of Lucas and Colerus), noting in particular that sources

1665," Revue des sciences philosophiques et théologiques 71 (1987): 9-21 and Richard H. Popkin, "Spinoza’s Earliest Philosophical Years, (1655-61),” Studia Spinozana, 4 (1988): 37-55; Jonathan I. Israel, Radical Enlightenment: Philosophy and the Making of Modernity, 1650-1750 (Oxford: Oxford University Press, 2001), $159 \mathrm{ff}$.

41 Richard H. Popkin, The History of Scepticism from Erasmus to Spinoza (Berkeley: University of California Press, 1979), and Popkin, "Menasseh ben Israel and Isaac La Peyrère,” Studia Rosenthaliana 8 (1974): 59-63; “The Development of Religious Scepticism and the Influence of Isaac La Peyrère's PreAdamism and Bible Criticism," in Classical Influences on European Culture, 1500-1700, edited by Robert R. Bolbar (Cambridge: Cambridge University Press, 1976): 271-280.

42 I. Orobio de Castro, “Tertium scriptum Judaei,” in Philippus van Limborch, De veritate religionis Christianae amica collatio cum erudito Judæo (Gouda: Justus van der Hoeve, 1687): 148.

43 See among others Robert Mizrahi, Spinoza (Paris: Seghers, 1964) and Sylvain Zac, Signification et valeur de l'interprétation de l'Écriture chez Spinoza (Paris: PUF, 1965).

44 Popkin's analyses, which highlight the impact of the rediscovered writings of Sextus Empiricus, have attracted objections and amendments in recent research, as this is stated in particular by Yosef Kaplan, “Richard Popkin's Marrano Problem," in The Legacies of Richard Popkin, edited by Jeremy D. Popkin (Dordrecht: Springer, 2008): 197-212; and Carsten L. Wilke, “"That Devilish Invention called Faith': Seventeenth-Century Free-Thought and its Use in Sephardi Apologetics," in Conversos, Marrani e Nuove Comunità ebraiche in età moderna, edited by Myriam Silvera (Florence: Giuntina, 2015): 131144, here 131-133.

45 Jacqueline Lagrée and Pierre-François Moreau, "La lecture de la Bible dans le cercle de Spinoza," in Le Grand Siècle de la Bible, edited by Jean-Robert Armogathe (Paris: Beauchesne-CNRS, 1989): $108-114$.

46 Wim Klever, “Proto-Spinoza Franciscus van den Enden,” Studia Spinozana 6 (1990): 281-289. 
refer to the Dutch master and his disciples as "atheist Cartesians" and that the Tractatus de Intellectus Emendatione was written around 1656-1657.47

The herem against Spinoza was pronounced in 1656, while Prado chose to submit to a public act of repentance. At a time when the two men were provisionally separated, Prado opened up to Daniel de Ribera, a priest who had become a proselyte to Judaism around 1653 and had opened a school in Amsterdam for the instruction of poor children. We can probably identify Ribera with the Catalan Don José Carreras y Coligo, who was a preacher in Portugal and a royal columnist in Brazil. ${ }^{48}$ In $1656-$ 1657, Prado seems to have been in close contact with Ribera (perhaps he even taught at the latter's school) to such an extent that their spiritual attitude increasingly invited concerns of the congregation and led to its special supervision. Soon, the Jewish leadership conducted an investigation, which resulted in two files. ${ }^{49}$ Four of Prado's students reported that their teacher had ridiculed various precepts of rabbinic ritual law, that he had doubted the truth of the Mosaic accounts and dismissed the belief in otherworldly retribution. In the remarks attributed to Prado, one finds two major elements of his thought: on the one hand, there is a claim to rational certainty and the equation of religious tradition with a chimaera (tudo era fantastico); on the other hand, Prado reflects the historicist interpretation of the Scriptures, as well as sceptic relativism of religious truth claims, that can be found elsewhere among the freethinkers of the time. By invoking natural reason and logic, Prado takes a stand outside the religious sphere, so that his ideas transcend even the heterodox currents that, in Maurice Kriegel's words, searched for "an original state of religious life"

47 Omero Proietti, "Lettres à Lucilius, une source du TIE de Spinoza," in Lire et traduire Spinoza: Travaux et documents, edited by Pierre-François Moreau (Paris: Presses de l'Université de Paris-Sorbonne, 1989), 9-39 (who, just as Alexandre Matheron, emphasises the Stoic influence on Spinoza's thought), and Wim Klever, "Spinoza 'corruptor' de Prado o la teoría de Gebhardt y Révah invertida," in Spinoza y España: 217-228. These theses were criticised by Miquel Beltrán, Un espejo extraviado: Spinoza y la filosofía hispano-judía (Barcelona: Riopiedras, 1998), 12.

48 Révah, "Aux origines de la rupture spinozienne: nouveaux documents," 369; and Révah, "Aux origines de la rupture spinozienne: Nouvel examen des origines, du déroulement et des conséquences de l'affaire Spinoza-Prado-Ribera," Annuaire du Collège de France 71 (1970-1971); Annuaire du Collège de France: 562-568; Annuaire du Collège de France 72 (1971-1972): 574-587; Annuaire du Collège de France 73 (1972-1973): 641-653, here 71, 563. See also the dedicatory poems of Juan de Prado to Manuel de Pina in Révah, “Aux origines de la rupture spinozienne: Nouveaux documents," 408 410; and the identification of Ribera with José Carreras in the inquiry by the Jewish congregation made in 1658 (SAA, PA 334, no. 882, fol. 3; Révah, "Aux origines de la rupture spinozienne: Nouveaux documents," 406).

49 SAA, PA 334, No 882, "Stukken betreffende de ban opgelegd aan Daniel de Prado en Daniel Ribera" (1658); published by Révah, "Aux origines de la rupture spinozienne: Nouveaux documents," 391-408; see Révah, “Aux origines de la rupture spinozienne: Nouveaux documents," 371-372, and Kaplan, From Christianity to Judaism, 139-142. 
and proposed a reformist position, as this was frequently adopted by Marranos disillusioned with normative Judaism. ${ }^{50}$

The congregational authorities brought the trials against Prado and Ribera to a swift conclusion. Ribera disappeared from Amsterdam and may have found refuge in London, ${ }^{51}$ but Prado was struck with the herem in February 1658. The banishment formula accuses him of having reverted to his "malicious and false opinions" and of having inculcated them to "some young students." It is proclaimed that no member of the congregation should henceforth communicate with him "by oral conversation or in writing, neither in this city or outside it, except the people of his family." 52 Prado tried in vain to obtain a cancelation of the verdict, and he even solicited the mahamad (community board) of Hamburg. ${ }^{53}$ At the same time, his son David de Prado transmitted to the mahamad in Amsterdam a Latin apology that his father had written with the intention to have it printed. Prado affirmed his orthodoxy, his attachment to Judaism, manifested by the fact that he had rejected certain prestigious university appointments that were offered to him on the condition that he changed his religion. He had taught his pupils "the norms of certainty" by explaining to them "that we know certain things by natural light, others by syllogistic reasoning, others by experience, and others finally by faith," thus invoking different levels of knowledge that recall Spinoza's "modes of perception." 54 He recognised that he had affirmed certain heterodox opinions, but he had done so without obstinacy, and no one had ever accused him of transgressing the law in practice. He blamed his errors on his human frailty, proclaimed his good intentions, and asked that his repentance be accepted with the same forgiveness with which the Marranos were welcomed back to Judaism. He finally pleaded for his family members who, although innocent, suffered the effects of the sanction..$^{55}$ The mahamad decided that the herem would only be lifted if Prado resigned to resettle in a Jewish community overseas. ${ }^{56}$

50 Maurice Kriegel, “Du marranisme au 'néo-judaïsme’: Migrations et reconfigurations identitaires dans l'Europe moderne (XV ${ }^{\text {ème }}$-XVIII ${ }^{\text {ème }}$ siècles),” in Creencias y culturas, edited by Carlos Carrete Parrondo and Alisa Meyuhas Ginio (Salamanca: Universidad Pontificia de Salamanca / Tel-Aviv University, 1998): 113-128, here 123.

51 Révah, “Aux origines de la rupture spinozienne, nouvel examen,” vol. 70, 563; Cecil Roth, A History of the Jews in England (Oxford: Clarendon Press, 1978), 179, note 1; Lucien Wolf, Judios en las Islas Canarias (Calendario de los casos judíos extraidos de los archivos de la Inquisición canaria de la colección del Marques de Bute), (La Orotrava, J.A.D.L., 1988 [1926]), 209, 210, 233, 249, and 251.

52 Révah, Spinoza, 58-59. The herem against Prado does not mention heretical writings, contrary to the one against Spinoza, which prohibits "leer papel algum feito ou escritto p[or] elle," 58.

53 Quoted by Carl Gebhardt, “Juan de Prado," in Chronicon Spinozanum, III (The Hague: Mouton \& Co, 1923): 269-291, here 278.

54 Benedict de Spinoza, Treatise on the Improvement of the Understanding / The Ethics / Correspondence, translated from the Latin with an introduction by R. H. M. Elwes (New York: Dover Publications, 2012 [1955]), 8-11.

55 SAA, PA 334 no. 882, fols. 9-12, 14, 16-17.

56 SAA, PA 334, no. 19, fol. 428. 
Prado, however, refused to emigrate. Staying in Amsterdam in spite of the herem, he found an ideal companion in Spinoza. The relations between the two banished men seem to have been close, according to the testimony that a Spanish Augustin friar, Tomas Solano y Robles, and the soldier Captain Miguel Pérez de Maltranilla gave to the Inquisition about their stay in Amsterdam during the winter of 1658 1659. They frequented gatherings in the house of Doctor Abraham Reynoso, a colleague whom Prado had already known in Andalusia, together with other members of the Amsterdam Jewish community, namely Samuel Pacheco, a former confectioner, and the barber Abraham Israel, who had both arrived from Spain some fifteen years earlier. Solano declares that Prado and Spinoza "happily confessed the error of atheism, because they thought that there was no God except in a philosophical sense ... that the soul died with the bodies and that they therefore had no need of faith," 57 which seems to show that the two friends had already broken with JudeoChristian theism. The testimonies given by Solano and Maltranilla, as well as the investigation of 1658, allow us to identify the staple elements of Prado's thought. He rejected the doctrine of creation in the name of the eternity of the world; he emphasised the authority of reason and the validity of a Cartesian type of proof; at the same time, he distinguished between various coexistent modes of knowledge, finally affirming the primacy of natural law.

From the years that follow, we lack traces of Prado in Amsterdam. His departure for Antwerp also brought about his separation from Spinoza, who settled in Rijnsburg near Leiden. In the spring of 1661, it was rumoured that he lived as a Catholic in Antwerp after accepting baptism with great pomp. During the following year, he was said to have frequented "the church of the Lutherans and tried to be one of them, and then the church of the Calvinists and other sects, assuring each one of them that he wished to join its respective religion." 58 At the end of 1663, rumours circulated in Amsterdam according to which Prado was about to repent and wished to return to Judaism. Orobio, then a newcomer in the city, volunteered to answer the "doubts" that retained his former co-disciple in the grip of heresy.

\section{Controversy by Correspondence with Orobio}

The only remaining elements of the correspondence between Prado and Orobio are three texts that were written by Orobio and from where we must infer about the contents of the "doubts" formulated by Prado. Although the herem excluded in principle any communication with Prado, the mahamad does not seem to have objected to these exchanges, hoping perhaps that Orobio's invectives against Prado would succeed in extinguishing the influence that risked "infecting others who, outside the

57 Révah, Spinoza et le dr Juan de Prado, 66-68.

58 AHN, Inquisición, leg. 2374'. See Muchnik, Une vie marrane, 328-340. 
Jewish community, had given credit to him and his foolish sophisms." 59 This may explain why this controversy acquired such a wide publicity and why the Invective Epistle circulated in so many manuscript copies.

Orobio's first letter bears in most of its copies the title Invective Epistle against a Physician and Philosopher, who doubted or disbelieved the truth of the Sacred Scriptures, while allegedly acknowledging [the existence of] God and the law of Nature in order to cover up his malice. We learn here that Prado had initially, probably in 1662, sent a letter to Orobio under a pseudonym; when this letter remained unanswered, he wrote again, complaining of Orobio's hesitation to correspond with him. Orobio was not fooled by Prado's alleged resolution to repent, but he took advantage of the opportunity to develop his refutation of Prado's propositions into a general apology destined to confront the heterodox trends among the Jews of his age.

Historical research has revealed the fact that a heterodox undercurrent crisscrossed the nação (the transnational community of Portuguese Jews and conversos) and, in particular, the Amsterdam congregation. The existence of this group of freethinkers, far beyond Prado's individual case, provoked Orobio's ire and, moreover, the vast polemical and apologetic production that characterised the Sephardic Diaspora. From the works that Leone Modena authored in Venice during the 1610s and 1620s, until those of Rabbi David Nieto in London a century later, Jewish authors constantly polemicised against the "sect" of "atheists," "deists," "students," "Karaites," or possibly "politicians," and "libertines," or, as they were called in Spain, "Machiavellians" and "Sadduceans." "60 The presence of these dissenters was already apparent in the insistence with which Grotius, in his Remonstratie (1615) stated the urgent need to make sure that the Jews within the Amsterdam congregation would practice their faith according to its pure orthodoxy. ${ }^{61}$ The dedicatory letter of the book On the Resurrection of the Dead (1636) by Menasseh ben Israel is no less revealing. ${ }^{62}$ There was, according to these sources, a continuous succession of heterodox individuals, who, as Orobio writes with rancor in the prologue of his Invective Epistle, "try to in-

59 Orobio, Epístola Invectiva, in Révah, Spinoza, 90.

60 To the "sectarians" who diffuse "heresies and errors," Abraham Pereyra devotes one chapter (4.1) of his Espejo de la vanidad del mundo (Amsterdam: Alexandro Janse, 1671), 395-411. Orobio opposes the "politically minded" to the "pious" in his Carta al hijo del doctor Prado (in Révah, Spinoza, 150: “creen los píos, no los politicos”). On this matter, see among others Jonathan I. Israel, "Philosophy, Deism, and the Early Jewish Enlightenment (1655-1740)," in The Dutch Intersection: The Jews and the Netherlands in Modern History, edited by Yosef Kaplan (Leiden, Brill, 2008), 173-202, Yosef Kaplan, Judíos nuevos en Amsterdam: Estudios sobre la historia social e intelectual del judaísmo sefardí en el siglo XVII (Barcelona: Gedisa, 1996); C. L. Wilke, "That Devilish Invention called Faith.”

61 Jacob Meijer, “Hugo Grotius’ Remonstratie,” Jewish Social Studies 17 (1955): 91-104, here 97-98 and Y. Kaplan, Judios Nuevos en Amsterdam, 34, note 28.

62 Menasseh ben Israel, De la resurreccion de los muertos (Amsterdam: En casa, y à costa del autor, 1636), fol. 4v, 25r-27v: "Considerando pues la nesaria maldad de los Zaduceos en todo depravados, y como oy en este miserable siglo se van algunos persuadiendo a la mortalidad de las almas, para mas a rienda suelta, se dexaren llevar de sus lassivos apetitos, me determine à escrevir este libro.” 
troduce their malice into the souls of the simple-minded,"63 as this happened apparently with the students whom Prado and Ribera had tried to "pervert." These freethinkers were, he wrote, trouble-makers, capable of spreading a sort of latent or passive incredulity, an attitude that Abraham Pereyra, among others, attacks in his Mirror of the Vanity of the World: "I am painfully concerned when I consider the superficial religion that so many display under the cover of the law. Even though they do not commit any abominations, they bear the title of Jews simply out of reason of state." ${ }^{64}$ Pereyra then details five forms of deviance that pervert the congregation. There is the arrogance of those who live apart from the community, the malignity of those who challenge the authority of the rabbis, the vanity of those who mock the divine precepts, the ambition of those who despise the preachers, and the obstinacy of those who persevere in their corrupt ways. ${ }^{65}$ Further, Pereyra lambasts the "double-faced" individuals who hide their true convictions in order to better corrupt their co-religionists. ${ }^{66}$ De Barrios finds similar tones in his "Table of the Holy Fraternity of the Kahal Kadosh of Amsterdam" (1683): “There are many who, though shrouded in the garb of the true religion, only wear it in order to dissimulate their evil intentions. The swan has white feathers to cover his black flesh." ${ }^{67}$

In sum, Orobio's Invective Epistle launches a sweeping attack on all the heterodox positions, and we can certainly not attribute to Prado each and every standpoint that is refuted therein. Orobio indeed displays a broad spectrum of heresies one by one, each calling for a refutation of its own. ${ }^{68}$ In the first chapter of the third discourse, he distinguishes, for example, three categories among the "followers of impiety, adversaries of virtue, lovers of their own whimsical understanding." "The first category, and those of the worst quality, are the heinous atheists, who daringly negate the Holy Scripture, though they use to excuse this with acknowledging [the existence of] a First Cause." Obviously, these "atheists" are in fact deists, whose perfidious belief Orobio denounces tirelessly. The second category are "Israelites who believe in God, accept the Holy Scripture, but detest the explanation that God Himself with supreme providence has provided to the Law," that is, those who reject the Talmud, such as the Sadduceans and the Karaites. The last, seemingly inoffensive

63 Orobio, Epístola Invectiva, in Révah, Spinoza, 90.

64 Pereyra, Espejo de la vanidad del mundo, 296; cf. Henry Méchoulan, "Los judíos de Amsterdam y Spinoza," in Spinoza y España: 49-56.

65 Pereyra, Espejo de la vanidad del mundo, 522, cf. Henry Méchoulan “Abraham Pereyra, juge des marranes et censeur de ses coreligionnaires à Amsterdam au temps de Spinoza,” Revue des études juives 138 (1979): 391-400, here 395.

66 Pereyra, Espejo de la vanidad del mundo, 396.

67 Miguel de Barrios, Tabla de la sacrales hermandades del Kahal Kados amstelodamo: Abi Ietomim, “Academia primera caritativa," in De Barrios, Triumpho del Govierno Popular (Amsterdam, 1683) [copy BL 127 e 18], fol. 44: "Muchos ay que, con vestirse, de Religion verdadera, solo toman el vestido, para encubrir sus cautelas. El cisne con blancas plumas, oculta su carne negra,” quoted also by $\mathrm{H}$. Méchoulan, "Los judíos de Amsterdam y Spinoza," 52-53.

68 Orobio, Epístola, in Révah, Spinoza, 126-127. See here for the following quotations. 
category, are in fact the most dangerous in Orobio's eyes, precisely because they are the least recognisable, namely those who observe both the written and the oral law, "but they are piteously lacking in the observance of the holy commandments," the rabbinic fences, which they reject "not only as superfluous, but even as contradicting the written law, because they believe that it is an attack on the divine precept to take away or add anything from its decrees." But I would see the most interesting element of Orobio's enumeration in the succession between these three categories, which become stages of a unified mental itinerary:

The disbelief (discredito) in the admonitions and fences that our Sages have established for the sake of a more perfect observance of the Law leads them surreptitiously to the disbelief in tradition and even in Scripture, whence they finally fall into atheism, as this is confirmed by the continuous experience of many who made this hapless journey, which always starts with the contempt for our Sages and their prudent and holy exhortations, and which ends in the most horrendous apostasy. ${ }^{69}$

The process described by Orobio can, for sure, be detected in Uriel da Costa's biography, ${ }^{70}$ but it is less clear for Prado, who manifested his first doubts in Andalusia when he was still ignorant of normative Judaism. We cannot speak here, as with respect to Uriel da Costa, of a "crisis within Judaism"71 attributable to Karaite inspiration, because Prado had no real familiarity with normative Judaism before his exile. According to Orobio, Prado's development was influenced by New Christians turned New Jews, persons who, like him, had studied at Spanish universities and were full of self-assurance. In the famous prologue to his Invective Epistle,$^{72}$ he distinguishes between two types of New Jews: those who "devote all their desire to love God's Law by endeavouring to learn, as much as their understanding is capable of, what is necessary to observe religiously its holy precepts, statutes, and ceremonies," and who listen humbly to those who are born as Jews. "These came sick of ignorance, but as the latter was not aggravated by the pernicious illness of pride, they recovered easily." Others, however, who "had studied under idolatry some secular sciences," were no less ignorant about Judaism than the first group,

69 Orobio, Epístola, in Révah, Spinoza, 127: "El descredito a las prevenciones o vallados de nuestros Doctores para la mas perfecta observancia de la ley, tacitamente los conduce al desprecio de la tradiccion, y despues de los escripto passando ultimamente en el Atheysmo, como lo verifican continuadas experiencias de nuebos [Révah: muchos] que hicieron este Ynfelize viage, principiando por el desprecio de nuestros Doctores, y sus prudentes y sanctas advertencias, hasta llegar a lo mas horrible de la apostasia."

70 Révah, Spinoza, 18; Jean-Pierre, Osier, D’Uriel da Costa à Spinoza (Paris: Berg International, 1983), $141-143$.

71 Jean-Pierre Osier, “Un aspect du judaïsme individualiste d'Uriel da Costa,” Cahiers Spinoza 3 (1979-1980), 101-115.

72 Orobio, Epístola, in Révah, Spinoza, 89-90. See here for the following quotations. 
but full of fickleness, pride, arrogance, convinced that they are distinguished scholars in all kinds of matters ... by inventing sophistic reasonings without any basis, they search recognition for their genius, acumen, and science. What is worse, they obtain this reputation among certain persons who because of their low age or their evil character boast to be smart, and although they do not understand a word of what the foolish philosopher argues against God's Law, they nevertheless pretend to understand him. ${ }^{73}$

One recognises in this second group a clear allusion to the would-be scholars who, like Prado, remained walled in their alleged certainties and, still worse, spread them, mainly among young people-a reference to the students in the trial of 1658 that Orobio had surely heard about. This type of interpretation resembles in part the reasons given since antiquity for the origins of atheism: however unstudied or freethinking they may be, atheists like to distinguish themselves by their taste and their expertise in literature, art, or philosophy, an image that one rediscovers in the seventeenthcentury concept of libertinage érudit (learned libertinism). Having studied in Spanish universities, Orobio certainly had an interest to insist on this fact in order to distinguish himself from this category of "philosophers."

The text is divided into four "discourses" (discursos) and on a second level into twenty-nine chapters, each one corresponding to one of Prado's “doubts" or to a counter-argument in Orobio's apology. In his first discourse, Orobio proves that the Torah is of divine origin and that it does not contradict natural reason, his central line of argument being that the denial of the "written law," the scriptural revelation, is tantamount to a denial of God's existence. In the second discourse, he defends the "oral law," without which Scripture cannot be adequately followed. In the third one, he supports the rabbinic fences that are necessary in order to protect the Torah against transgression in the course of human history. Finally, the last part "defends the purity and honesty of the Talmud against trumped-up and malicious slander."74

The more the reader advances in the Invective Epistle, the fewer references there are to Prado and his objections. One may generally succeed in identifying Prado's "doubts" in the text, but it is impossible to find out which one may have been inspired by Spinoza's first work, the Apology Justifying his Abdication from the Synagogue, as well as by his acquaintance with the young philosopher, and to point to the ideas that are due to Prado in particular. In the first discourse, Orobio refers to Prado's basic postulate in the following way: "the deists hold that their belief in God's unity and eternity has so much certainty for them that it is not a conjecture or an

73 Orobio, Epístola, in Révah, Spinoza, 90: "mas llenos de variedad, de sobervia, de altivez, persuadidos que son doctissimos en todas materias [...] con hacer argumentos sophisticos sin fundamento alguno, se acreditan de ingeniosos, de agudos, de scientes; Lo peor es, que consiguen esta opinion entre algunos que, o por sus pocos años, o por su mal natural, presumen de discretos, y aunque no entienden cosa de lo que dice el nescio philosopho contra la Ley de Dios, con todo hacen como que lo entienden."

74 Orobio, Epístola, in Révah, Spinoza, 128: "Defiendese la pureza y sinceridad del Talmud contra las inventadas y maliciosas calumnias." 
opinion, because in this case they would admit doubt and not believe in it with infallible certainty." ${ }^{75}$ Prado seems to recognise that God has created the universe but not the "book" that announces this truth. Prado's creator-God is, like that of the French deists, an insensible God who, after having created the universe, abandons it to the natural laws, which are the only way in which he exerts his providence: in consequence, there cannot be singular interventions or miracles. ${ }^{76}$ According to Orobio, however, whoever does not acknowledge that particular events are governed by divine providence does not actually believe in the existence of God.

One of the most central questions in the Invective Epistle deals with the divine election of the Jews. ${ }^{77}$ Why did the Creator choose Israel? Why did the enormous miracles fail to convince the other nations of Israel's chosenness? Prado seems to have argued that Israel was not the only nation that had prophets and a divine revelation, a thesis that I. S. Révah compares with chapter 3 of Spinoza's Theological Political Treatise, "On the vocation of the Hebrews, and whether the prophetic gift was peculiar to them," 78 which may reflect ideas from his Apology. However, the question of Israel's chosenness appears frequently in the apologetic literature of the Portuguese Jews. ${ }^{79}$ Some historians have highlighted the possible influence of certain Hispanic thinkers expressing disillusion (desengaño), who claimed that the political decline of Spain was due to its messianic and mystical delusions, including the discrimination against the New Christians and the negative prejudice against the middle class professions that were usually associated with them. ${ }^{80}$

The eighth chapter of Orobio's first discourse replies to the objections against the divine origin of the Torah, which is suspected to be the result of a more recent mystification. Here, Orobio defends the antiquity of the text, which even the Christians have taken as the basis of their religion, and whose divine proof consists in the contingent events that are prophesied therein. ${ }^{81}$ In the eleventh chapter of the first discourse, Orobio continues by arguing that the belief in the existence of God, even in

75 Orobio, Epístola, in Révah, Spinoza, 119: “afirman los Deistas que tan cierto creen la Unidad y Eternidad de Dios que no la conjecturan o opinan, porque opinarla fuera dudar, y no creer con infalible certeza.”

76 Révah, Spinoza et le Dr Juan de Prado, 43-44.

77 Orobio, Epístola, first discourse, chapters 7 and 9, in Révah, Spinoza, 105-110, 112-113.

78 Benedict de Spinoza, Theological-Political Treatise, edited by Jonathan Israel (Cambridge: Cambridge University Press, 2007), 43.

79 See in particular the first chapter in Isaac Cardoso, Las Excelencias de los Hebreos (Amsterdam: David de Castro Tartas, 1679), fols. 1-22.

80 Such reformist discourse can be found, in particular, in a pamphlet of Martín González de Cellorigo, Memorial de la política necesaria y útil restauración a la república de España. See I. S. Révah, "Le plaidoyer en faveur des 'Nouveaux-Chrétiens' portugais du licencié Martín González de Cellorigo (1619),” Revue des études juives 122 (1963): 279-398; Kaplan, From Christianity to Judaism, 174-175, and Henry Méchoulan, “L'altérité juive dans la pensée espagnole (1550 -1650)," Studia Rosenthaliana 8 (1974): 31-58 and 171-202, here 189.

81 Orobio, Epístola, in Révah, Spinoza, 111-113. 
the way the deists confess it, is inseparably linked to the belief in the divinity of the scriptures. ${ }^{82}$

In the second discourse, which extols the rabbinic tradition, we can find elements that bring to mind the inquiry held in 1658 against Prado. Why has God not included the content of the oral law and the tradition within the written revelation? And if the written and the oral law have the same value, why did the first one need to be fixed in writing? Finally, why did God not formulate his law and precepts clearly enough to make further explanations superfluous? ${ }^{83}$

The third discourse reports Prado's attacks against the derivative commandments or "fences" promulgated by the ancient sages: the latter, he claimed, make the observance of the biblical precepts more difficult because they paradoxically give the Jewish believer more occasions to commit sins. ${ }^{84}$ The fourth discourse exposes the methods used by Prado and others of his ilk, who isolate a passage or a commandment from its context in order to reject and ridiculise the texts as being contradictory and obscure.

Doctor Prado, stung to the quick, was upset that Orobio accused him of denying the immortality of the soul, and in his response, he insisted upon his belief in a natural religion. Orobio sought to debunk this claim in a rejoinder, the Apologetic Letter to Doctor Prado by Doctor Isaac Orobio de Castro, which manifests the ambivalent feelings with which he engaged the controversy with Prado: he was torn between personal affection for the man and the repulsion against the positions that the latter had chosen to defend and, worse, to promote publicly. It seems that Prado was surprised by the connection that Orobio demanded between reason and faith, and that he urged the latter to clarify his thoughts.

Prado's deism does not admit the divine revelation that believers find in the Scriptures, while Orobio claims the universal consent of all monotheistic religions for the divinity of the Pentateuch. For Prado, the very content of certain biblical books, their legendary character, makes it impossible to believe in them; he declares that he would only abide by the law of Nature common to all men. But Orobio denies to him this possibility: "If you did not know that you are of Abraham's descendence, you would be allowed to acquire salvation in the law of Nature. However, as you

82 Orobio, Epístola, in Révah, Spinoza, 119-120.

83 Orobio, Epístola, in Révah, Spinoza, 123-126.

84 Orobio, Epístola, in Révah, Spinoza, 126: "La piedad juzga el impio sencillez indigna de la racionalidad, el esfuerço se calumnió varias vezes por temeridad, la sagrada justicia por rigor execrable, la verguença por cortedad de animo, la obediencia por servil rendimiento, lo religioso por hypocresia y la cuidadosa atencion en el divino culto por escrupulosa puerilidad." Révah unnecessarily corrects "escrupulosa puerilidad” into "escrupulos o puerilidad." 
know well that you are of Abraham's Israelite descendants, you can only obtain salvation by observing the law that God has commanded to this lineage."85

Orobio wrote a third letter to Prado, titled in one of the manuscripts Letter Written by Doctor Isaac Orobio de Castro to a Person in Antwerp against Doctor Prado, who Lived There, Being Separated from the Nation by Virtue of a Herem [ban] that was Proclaimed in the Synagogue of Amsterdam. This letter was probably composed in 1664 and addressed to Prado's son David. ${ }^{86}$ Orobio was prudent enough to show that the Jewish community did not approve of his pursuing the controversy. Someone speaking on behalf of Prado had asked him three questions and Orobio had consented to answer them without corresponding directly with his excommunicated friend. These three questions express the gist of Prado's critique of tradition: "How can it be that some persons find a certain thing reasonable and agree with a certain proposition, while others dislike it and disagree, although all souls are of the same nature and substance?" ${ }^{87}$ Here, the relativity of opinions questions the criteria of truth. The second question "concerns moral philosophy and expresses doubt about the following: if there are two or more legislators and each one emits and promulgates a different law by claiming divine origin for it, which is the one that the understanding should follow: the one that it disapproves, but that others recommend as the right one, or the one that it approves though others say that it is bad?" 88 This second question conjures up the issues of free will and individual conscience. The last question refers to the innocence of pagans and other non-Jews who transgress the divine law because they do not know the truth.

For the same reason that the innocent child does not sin, even though it commits an act that would be a sin in an adult person, because it performs the act without an evil intention, people who by ignorance go astray from the true path and fall into error should not be considered as sinners either, because they believe that they are acting rightly. ${ }^{89}$

85 Orobio, Epístola, in Révah, Spinoza, 140: "Si no supiera que era posteridad de Abraham, pudiera Vmd salvarse en la Ley Natural: mas, sabiendo que es posteridad Isrraelitica de Abraham, está obligado para salvarse a guardar la Ley que Dios encomendó a esta posteridad.”

86 Orobio, Carta al hijo del Doctor Prado, in Révah, Spinoza, 143-153; another copy, dated from 1712, is preserved in Ets Haim ms. 48 A 21, fols. 239-251, see the quoted title here at fol. 239.

87 Orobio, Carta al hijo del Doctor Prado, in Révah, Spinoza, 144: "porque a unos les parece bien una cosa y assienten a una proposicion, y a otros mal y dissienten della, siendo las almas de una misma substancia y naturaleza?"

88 Orobio, Carta al hijo del Doctor Prado, in Révah, Spinoza, 146: "La segunda pregunta toca a la Philosophia Moral y duda: si ay dos Legisladores o mas, y cada uno intima y promulga ley contraria con titulo de divina, qual ha de seguir el entendimiento, la que le parece mal porque le aconsejan otros que es buena, o la que le parece bien aunque otros le digan que es mala?"

89 Orobio, Carta al hijo del Doctor Prado, in Révah, Spinoza, 151: "Que por esso el niño innocente no peca, aunque haga acto que fuera pecado en el adulto: porque no conoce la malicia de aquel acto. Luego, los hombres que yerran el verdadero camino, no conociendo que yerran, tampoco deven ser tenidos por pecadores, pues ellos piensan que aciertan.” 
We should remember that this problem was much discussed at the time, especially in the Iberian countries with respect to Native Americans. ${ }^{90}$ The objective of all these questions was quite clear for Orobio: "His intention is to prove that no person is obliged to follow a certain religion more than another, that it is indifferent by which way one seeks to please God, and by consequence there is no divine law, but only human resources that each one considers as divine."91 Orobio now repeats his preceding arguments, with a special emphasis on the problem of otherworldly rewards and punishments.

This letter marks probably the final point of the controversy between the two friends, who would henceforth pursue contrary paths. The end of the Letter to Doctor Prado's Son shows that Orobio has given up all hope of convincing Prado: "As this subject transcends reason so much, I cannot pursue it further than to where the lowliness of my argument may reach."92 This was the last effort that any member of the Jewish congregation of Amsterdam undertook to bring the lost son back to orthodox ways. While Orobio continued his ascension towards the highest ranks of congregational leadership, Prado definitively moved away from Judaism. In June 1667, he asked Don Francisco Lugo del Castillo, a member of elite society in the Canary Islands and perpetual local governor (regidor) of Tenerife, to help him obtain from the Inquisition the permission to settle in the Canaries. Prado wrote two texts with the intention of obtaining an Inquisitorial reconciliation without risking imprisonment or confiscation of property. When these writings arrived at the Holy Office two years later, they aroused many emotions throughout the Peninsula. ${ }^{93}$ It was then, or soon after, that Prado died of a fall from his horse, a tragic end on which the Amsterdam poet Miguel de Barrios commented with irony in 1672: "The divine Justice punished Doctor Juan de Prado, master of false dogmas, who had not more religion than what was convenient for his body, and no more soul, in his opinion, than a horse." 94

90 Among other studies, see the (controversial) analyses by Stuart Schwartz, All Can Be Saved: Religious Tolerance and Salvation in the Iberian Atlantic World (New Haven: Yale University Press, 2009). 91 Orobio, Carta al hijo del Doctor Prado, in Révah, Spinoza, 147: "Su intencion es provar que no está el hombre obligado a una religion mas que a otra, que es indiferente el camino para agradar a Dios y que, consiguientemente, no ay Ley Divina, sino medios humanos que cada uno tiene por divinos." 92 Orobio, Carta al hijo del Doctor Prado, in Révah, Spinoza, 153: "En materia tan sobre la razon, no puedo discurrir mas que hasta donde alcança la poquedad de mi discurso.”

93 Luis Alberto Anaya Hernández, “El Doctor D. Juan de Prado y la Inquisición canaria,” Historia Social, 32 (1998): 133-144; Muchnik, Une vie marrane, 331-336.

94 Barrios, Coro de las Musas, fol. 355: "Castiga la Divina Justicia al Doctor Juan de Prado, maestro de falsos dogmas, que no tenia mas religion que la que convenia a su cuerpo, ni mas alma en su opinion que de cavallo." 
Of the three polemical texts written by Orobio against his free-thinking friend, ${ }^{95}$ the Invective Epistle would be transmitted for generations among the Jews of Amsterdam: at least fifteen copies can still be located today. The Apologetic Letter, which survives in a single copy, owes its scarce circulation probably to its more personal and confidential tone. Three copies survive of the Letter to Prado's Son, two in the Ets Haim Seminary and a very late one, dated from 1731, in the National Library of Paris. The latter manuscript is the only textual witness that offers all three anti-Pradian essays; with respect to the Letter to Prado's Son, its wording also seems to be closer to the original and contain less scribal errors than the manuscripts kept at the Ets Haim library. Most interestingly, the Paris manuscript contains a number of anti-Christian remarks that are missing from the two Amsterdam texts. For example, one sentence mentions the idea that eternal damnation awaits the Christians, because "they acknowledge the truth of the Law of Moses, yet they observe the contrary of what is taught in it, and they believe in dogmas contrary to natural reason." 96 A possessor of the manuscript has apparently expurgated these polemical remarks against Christianity; it is even possible to imagine that it was the mahamad (the community leadership) who examined the text meticulously and who censored these and other passages that risked scandalising possible non-Jewish readers. In any case, the transmission of Orobio's three works against Prado, which covers the period from 1663 to 1731, shows an effort to impose a separation between two overlapping literatures, distinguishing on the one hand the apologetic discourse against irreligion and on the other hand the polemical literature against Christianity that was subject to a particular precaution.

\section{Translated from the French by Carsten Wilke}

\section{Works Cited}

Archivo Diocesano de Cuenca [ADC], Inquisición, leg. 492 (6569).

Archivo Histórico Nacional [henceforth AHN], Inquisición, leg. 2374¹.

AHN, Inquisición, leg. $2987^{1}$.

AHN, Inquisición, lib. 1134.

AHN, Universidades, lib. 493F.

Stadsarchief Amsterdam [henceforth SAA], Collegium Medicum, Series nominum doctorum medicinae, no. 16.

SAA, PA 334, no. 19.

SAA, PA 334, no. 882.

SAA, PA 334, no. 1186.

95 See the list in From Christianity to Judaism, 431-433. The following remarks on the textual transmission of the three essays are based on Kaplan, From Christianity to Judaism, 154-156, and Muchnik, Une vie marrane, 462-464.

96 Kaplan, From Christianity to Judaism, 448. 
Albiac, Gabriel. La sinagoga vacía: Un estudio de las fuentes marranas del espinosismo. Madrid: Hiperión, 1987.

Alejandre, Juan Antonio and María Jesus Torquemada. Palabra de hereje: La Inquisición de Sevilla ante el delito de proposiciones. Seville: Universidad de Sevilla, 1998.

Anaya Hernández, Luis Alberto. "El Doctor D. Juan de Prado y la Inquisición canaria." Historia Social 32 (1998): 133-144.

Baer, Yitzhak. A History of the Jews in Christian Spain. Philadelphia: Jewish Publication Society, 1966.

Barrios, Miguel de. Triumpho del Govierno Popular. Amsterdam: n.p., 1683. [copy British Library, 127 e 18]

Beltrán, Miquel Un espejo extraviado: Spinoza y la filosofía hispano-judía. Barcelona: Riopiedras, 1998.

Ben Israel, Menasseh. De la resurreccion de los muertos. Amsterdam: En casa, y à costa del autor, 1636.

Caballero, Práxedes. "La crítica de Orobio de Castro a Spinosa." In Spinoza y España, edited by Atilano Domínquez, 229-237. Murcia: Universidad de Castilla-La Mancha, 1994.

Calvo, Sagrario Muñoz. Inquisición y ciencia en la España moderna. Madrid: Editora Nacional, 1977.

Cardoso, Fernando. Discurso sobre el Monte Vesuvio, insigne por sus ruinas, famoso por la muerte de Plinio, del Prodigioso incendio del año passado de 1631. $i$ de sus causas naturales, $i$ el origen verdadero de los terremotos, vientos, i tempestades. Madrid: Francisco Martinez, 1632.

Cardoso, Isaac. Las Excelencias de los Hebreos. Amsterdam: David de Castro Tartas, 1679.

Caro Baroja, Julio. De la superstición al ateísmo: Meditaciones antropológicas. Madrid: Taurus, 1974.

Caro Baroja, Julio. Los judíos en la España moderna y contemporanea. Madrid: Istmo, 2000.

Ceñal, Ramón. "El argumento ontológico de la existencia de Dios en la escolástica de los siglos XVII y XVIII." In Homenaje a Xavier Zubiri, vol. 1, 247-325. Madrid: Moneda y Crédito, 1970.

Edwards, John. "Religious Faith and Doubt in Late Medieval Spain: Soria circa 1450-1500." Past and Present 120 (1988): 3-25.

Edwards, John and C. John Sommerville. "Religious Faith, Doubt and Atheism." Past and Present 128 (1990): $152-161$.

Gebhardt, Carl. "Juan de Prado." Chronicon Spinozanum 3 (1923): 269-291.

Gracian de la Madre de Dios, Geronimo. Diez lamentaciones del miserable estado de los Atheístas de nuestros tiempos. Brussels: Roger Velpio and Huberto Antonio, 1611.

Hurtado de Mendoza, Pedro. Disputationes de universa philosophia. Lyon: Antoine Pillehotte, 1617.

Israel, Jonathan. "Philosophy, Deism, and the Early Jewish Enlightenment (1655-1740)." In The Dutch Intersection: The Jews and the Netherlands in Modern History, edited by Yosef Kaplan, 173-202. Leiden: Brill, 2008.

Israel, Jonathan. Radical Enlightenment: Philosophy and the Making of Modernity, 1650-1750. Oxford: Oxford University Press, 2001.

Kaplan, Yosef. From Christianity to Judaism: The Story of Isaac Orobio de Castro. Oxford: Littman Library; Oxford University Press, 1989.

Kaplan, Yosef. "Foi et scepticisme dans la diaspora des nouveaux-chrétiens des débuts de l'Europe moderne." Arquivos do Centro Cultural Calouste Gulbenkian 48 (2004): 21-40.

Kaplan, Yosef. Judios nuevos en Amsterdam: Estudios sobre la historia social e intelectual del judaísmo sefardí en el siglo XVII. Barcelona: Gedisa, 1996.

Kaplan, Yosef. "Richard Popkin's Marrano Problem." In The Legacies of Richard Popkin, edited by Jeremy D. Popkin, 197-212. Dordrecht: Springer, 2008. 
Klever, Wim. “Proto-Spinoza Franciscus van den Enden.” Studia Spinozana 6 (1990): 281-289.

Klever, Wim. "Spinoza 'corruptor' de Prado o la Teoría de Gebhardt y Révah invertida." In Spinoza y España, edited by Atilano Domínquez, 217-228. Murcia: Universidad de Castilla-La Mancha, 1994.

Kriegel, Maurice “Du marranisme au 'néo-judaïsme’: Migrations et reconfigurations identitaires dans l'Europe moderne (XVème-XVIII İ̀me siècles)." In Creencias y culturas, edited by Carlos Carrete Parrondo and Alisa Meyuhas Ginio, 113-128. Salamanca: Universidad Pontificia de Salamanca-Tel-Aviv University, 1998.

Lagrée, Jacqueline and Pierre-François Moreau. "La lecture de la Bible dans le cercle de Spinoza." In Le Grand Siècle de la Bible, edited by Jean-Robert Armogathe, 108-114. Paris: Beauchesne-CNRS, 1989.

Limborch, Philippus van. De veritate religionis Christianae amica collatio cum erudito Judæo. Gouda: Justus van der Hoeve, 1687.

Méchoulan, Henry. "Abraham Pereyra, juge des marranes et censeur de ses coreligionnaires à Amsterdam au temps de Spinoza.” Revue des études juives 138 (1979): 391-400.

Méchoulan, Henry. "L'altérité juive dans la pensée espagnole (1550-1650)." Studia Rosenthaliana 8 (1974): 31-58, 171-202.

Méchoulan, Henry. "Los judíos de Amsterdam y Spinoza.” In Spinoza y España, edited by Atilano Domínquez, 49-56. Murcia: Universidad de Castilla-La Mancha, 1994.

Meijer, Jacob. “Hugo Grotius' Remonstratie.” Jewish Social Studies 17 (1955): 91-104.

Meinsma, Koenrad O. Spinoza et son cercle. Paris: Vrin, 1983.

Mignini, Filippo. “Données et problèmes de la chronologie spinozienne entre 1656 et $1665 . "$ Revue des sciences philosophiques et théologiques 71 (1987): 9-21

Mizrahi, Robert. Spinoza. Paris: Seghers, 1964.

Muchnik, Natalia. Une vie marrane: Les pérégrinations de Juan de Prado dans l'Europe du XVIle siècle. Paris: Honoré Champion, 2005.

Orobio de Castro, Isaac. "Carta al hijo del doctor Prado." In Spinoza et le Dr Juan de Prado, edited by I. S. Révah, 143-153. Paris: Mouton \& Cie., 1959.

Orobio de Castro, Isaac. "Carta apologética." In Spinoza et le Dr Juan de Prado, edited by I. S. Révah, 130-142. Paris: Mouton \& Cie., 1959.

Orobio de Castro, Isaac. "Epístola invectiva." In Spinoza et le Dr Juan de Prado, edited by I. S. Révah, 84-129. Paris: Mouton \& Cie., 1959.

Osier, Jean-Pierre. D’Uriel da Costa à Spinoza. Paris: Berg International, 1983.

Osier, Jean-Pierre. “Un aspect du judaïsme individualiste d’Uriel da Costa.” Cahiers Spinoza 3 (1979-80): 101-115.

Pereyra, Abraham. Espejo de la vanidad del mundo. Amsterdam: Alexandro Janse, 1671.

Popkin, Richard H. “Menasseh ben Israel and Isaac La Peyrère." Studia Rosenthaliana 8 (1974): $59-63$.

Popkin, Richard H. “Spinoza’s Earliest Philosophical Years (1655-1661).” Studia Spinozana 4 (1988): 37-55.

Popkin, Richard H. "The Development of Religious Scepticism and the Influence of Isaac La Peyrère's Pre-Adamism and Bible Criticism." In Classical Influences on European Culture, 1500-1700, edited by Robert R. Bolbar, 271-280. Cambridge: Cambridge University Press, 1976.

Popkin, Richard H. The History of Scepticism from Erasmus to Spinoza. Berkeley: University of California Press, 1979.

Proietti, Omero. “Lettres à Lucilius, une source du TIE de Spinoza.” In Lire et traduire Spinoza: Travaux et documents, edited by Pierre-François Moreau, 9-39. Paris: Presses de l'Université de Paris-Sorbonne, 1989. 
Quevedo, Francisco de. Política de Dios y gobierno de Cristo. Buenos Aires: Espasa-Calpe Argentina, 1947.

Quevedo, Francisco de. Providencia de Dios padecida de los que la niegan y gozada de los que la confiessan: Doctrina estudiada en los gusanos y persecuciones de Job. Zaragoza: Pasqual Bueno, 1700.

Révah, I. S. "Antiquité et christianisme, anciens et modernes, dans l'œuvre de João de Barros." Revue philosophique de la France et de l'étranger 157 (1967): 165-18.

Révah, I. S. "Aux origines de la rupture spinozienne: Nouveaux documents sur l'incroyance dans la communauté judéo-portugaise à Amsterdam à l'époque de l'excommunication de Spinoza." Revue des études juives 123 (1964): 359-431.

Révah, I. S. "Aux origines de la rupture spinozienne: Nouvel examen des origines, du déroulement et des conséquences de l'affaire Spinoza-Prado-Ribera." Annuaire du Collège de France 71 (1970): 562-568; 72 (1971): 574-587; 73 (1972): 641-653.

Révah, I. S. Des Marranes à Spinoza. Edited by Henry Méchoulan, Pierre-François Moreau. and Carsten Lorenz Wilke. Paris: Vrin, 1995.

Révah, I. S. "Le colloque 'Ropicapnefma' de Joâo de Barros. Genèse, structure et technique." Bulletin Hispanique LXIV (1962): 572-592.

Révah, I. S. "Le plaidoyer en faveur des 'Nouveaux-Chrétiens' portugais du licencié Martín González de Cellorigo (1619).” Revue des Études Juives 122 (1963): 279-398.

Révah, I. S. Spinoza et le Dr Juan de Prado, Paris: Mouton \& Cie., 1959.

Roth, Cecil. A History of the Jews in England. Oxford: Clarendon Press, 1978.

Schwartz, Stuart. All Can Be Saved: Religious Tolerance and Salvation in the Iberian Atlantic World. New Haven: Yale University Press, 2009.

Spinoza, Benedict de. Treatise on the Improvement of the Understanding / The Ethics / Correspondence, translated from the Latin with an introduction by R. H. M. Elwes. New York: Dover Publications, 2012 (1955).

Spinoza, Benedict de. Theological-Political Treatise. Edited by Jonathan Israel. Cambridge: Cambridge University Press, 2007.

Suarez, Francisco. Metaphysicarum disputationum. Salamanca: Juan and Andres Renaut, 1597.

Wachtel, Nathan. La foi du souvenir. Labyrinthes marranes. Paris: Seuil, 2001.

Wilke, Carsten L. “'That Devilish Invention called Faith': Seventeenth-Century Free-Thought and its Use in Sephardi Apologetics." In Conversos, Marrani e Nuove Comunità ebraiche in età moderna, edited by Myriam Silvera, 131-144. Florence: Giuntina, 2015.

Wolf, Lucien. Judios en las Islas Canarias (Calendario de los casos judíos extraidos de los archivos de la Inquisición canaria de la colección del Marques de Bute). La Orotrava: J.A.D.L., 1988.

Yerushalmi, Yosef Hayim. From Spanish Court to Italian Ghetto: Isaac Cardoso, a Study in Seventeenth-Century Marranism and Jewish Apologetics. New York: Columbia University Press, 1971.

Yovel, Yirmiyahu. Spinoza and Other Heretics, vol.1: The Marrano of Reason. Princeton: Princeton University Press, 1989.

Yovel, Yirmiyahu. The Other Within: The Marranos, Split Identity and Emerging Modernity. Princeton: Princeton University Press, 2009.

Zac, Sylvain. Signification et valeur de l'interprétation de l'Écriture chez Spinoza. Paris: Presses Universitaires de France, 1965. 